\title{
The Railway and a Rare Colobus Monkey
}

\section{W.A. Rodgers, K.M. Homewood and John B. Hall}

The Tanzania-Zambia railway now bisects the Magombera Forest Reserve in Tanzania, and as a result the most viable surviving population of the rare endemic Iringa red colobus is seriously threatened. The railway has facilitated tree-felling, settlement and cultivation, and the colobus habitat is already seriously damaged. The authors conducted a survey of the forest in 1979 , and recommended that the southern part, which has a viable colobus population, be included in the neighbouring Selous Game Reserve, thus giving that part the stronger protection of a game reserve, and that the local people be compensated by the release to them of a small area of the Selous.

Magombera Forest Reserve, at the foot of the Uzungwa Highlands scarp in Tanzania $\left(36^{\circ} 55^{\prime} \mathrm{E} 7^{\circ} 50^{\prime} \mathrm{S}\right)$, is a remnant of lowland forest. Less than $11 \mathrm{sq} \mathrm{km}$ in extent, its alluvial soils are watered by a complex and unstable braided stream system draining off the escarpment into the low-lying Kilombero Valley $(300 \mathrm{~m}$ asl). Although by no means well studied the forest is known for its biological diversity, and the endemic plant and animal species have been described in a number of unpublished reports. Perhaps the most striking endemic is the Iringa or Uhehe red colobus monkey Colobus badius gordonorum, a rare subspecies restricted to Magombera and the Uzungwa Highland forests. ${ }^{2}$

Struhsaker (1978) describes this monkey as having the most brilliant and contrasting colour patterns of all the red colobus subspecies, with a vivid red crown, a fringe of black hair round the pink and grey face, white belly, and dark grey back; some individuals have a pattern of red at the base of the tail. A recent survey of Magombera and the Uzungwa Highlands has established that Magombera has the highest density and probably the largest and most viable remaining population of this primate. ${ }^{1}$

Although a forest reserve, Magombera has been severely damaged by the construction of the Tanzania-Zambia railway which bisects it, by associated timber exploitation, and by the subsequent pressure of new and expanding settlements along the periphery. In 1979 members of the Wildlife and Forestry Departments of the University of Dar es Salaam carried out surveys of the vegetation and primate populations, relating them to the present conservation status. This paper summarises the results and considers appropriate long-term conservation action.

\section{Vegetation}

Magombera Forest comprises almost $11 \mathrm{sq} \mathrm{km}$ of tall ( $30 \mathrm{~m}$ canopy), semi-deciduous forest widely dominated by Erythrophleum sauveolens, and more locally by Xylopia parvifolia and Isoberlinia scheffleri. The understory is dominated by Rubiaceae, Annonaceae and Apocynaceae species. The swampy western edge of the forest has a lower more open canopy of Syzygium guineense and Vitex doniana. Natural glades of wet grassland occur along the braided drainage lines. From two $25 \mathrm{~m}$ x $25 \mathrm{~m}$ vegetation plots 147 species of vascular 
plant were recorded, indicating a very high species richness comparable to those of the moist lowland forests of West Africa. This is believed to indicate that the vegetation is a relict of forest cover that was once much more extensive.

Floristically Magombera is related to the riverine and wet lowland forests of coastal East Africa. Such forests exist today only as fragments of their former cover, mainly for climatic reasons, but also due to increased fire and cultivation. These fragments are likely to have been isolated for up to 6000 years, a possible explanation of the presence of some woody species regarded as endemics (Polyalthia sp. nov., Ixora sp. nov., Memecylon magnifoliatum). Other occurrences of interest are of species now associated particularly with forests of the slopes of some mountain blocks, the surviving populations being widely separated because previous forest cover has become fragmented. Isoberlinia scheffleri and Isolona heinsenii are illustrations of this here.

\section{Primates}

The forest fauna comprises bushbuck, red duiker, suni, bushpig, cane rat, cape clawless otter, mountain squirrel, the rare scaly-tailed flying squirrel Anomalurus derbianus, a wide range of birds, reptiles and amphibians (including an endemic treefrog Hyperolius sp. nov.) and at least six primate species: red colobus, black and white colobus, Sykes and vervet monkeys, yellow baboon and a species of bushbaby. This makes Magombera one of the most diverse primate localities in Tanzania east of the Mahari Mountains and Gombe Stream, as well as one of the few areas where the red and the black and white colobus occur together.

The primate populations were censused with the help of Game Division staff and University wildlife students, and the results are summarised in Table 1. At least ten groups of red colobus were sighted within a total censused strip of 47.5 $\mathrm{km} \times 0.1 \mathrm{~km}$; extrapolation from this sample gives an estimate of 1.7 groups sq $\mathrm{km}$, or a probably total of about 18 groups in the whole forest. As seems characteristic for red colobus in disturbed habitat, mean group size was found to be rather low -25 individuals (Table 1), giving a minimum population of 250 individuals and a more probable estimated total of around 423 individuals. $^{34}$ There is a healthy proportion of subadults, juveniles and infants; on average, 50 per cent of group members are immature. The census gave estimates of 34 black and white colobus groups (mean group size of 6 ) and 42 Sykes groups remaining in the forest.

An analysis of association between individual primate species and areas of different canopy height and damage class showed red colobus to be associated with areas of high canopy forest (regardless of damage class) and black and whites with areas of low canopy damage (regardless of height class). Sykes monkeys showed no association with either canopy height or damage classes.

One feature of major ecological interest first noted by Struhsaker (1978) and confirmed on this and other surveys is the tendency for C.b. gordonorum to associate with black and white colobus in mixed groups. Fifteen out of 26 sightings of red colobus in Magombera were in association with black and whites; the same phenomenon was later observed for C.b. gordonorum in the Uzungwa Highland forests (where both reds and black and whites occur at far lower densities). Incidence of association between the two species in other areas where they occur together is less than one per cent of sightings. ${ }^{4}$ 


\section{TABLE 1 Population parameters: Red Colobus in Magombera Forest} Reserve

Forest Size

Number of individual groups sighted

Number of group counts

Estimated group density

Estimated mean group size range of group sizes

Estimated animal density

Estimated population size

Average group composition

Adult males

Adult females

Large juveniles

Small juveniles

Infants

Unidentified

$\%$ immature

Adult male:female ratio

Average number of adult males per group
$11 \mathrm{~km}^{2}$

10 (excludes resightings)

7 ( 4 by Struhsaker)

$1.7 / \mathrm{km}^{2}$

25

(1)-17-33

$42.5 / \mathrm{km}^{2}$

450

Percentage

10

34

20

8

14

14

45

$1: 3.5$

$2.4(1-5)$

\section{Present Conservation Status}

Magombera was declared a forest reserve in 1955 when an area of over $15 \mathrm{sq} \mathrm{km}$ was gazetted to allow the conservation and management of its valuable timber resources. Aerial photograph analysis shows a decrease of forest area by 1979 to some $11 \mathrm{sq} \mathrm{km}$. This habitat destruction is partly due to expansion of associated settlement around the forest and to construction of the Tazara railway. Cultivation, particularly rice, has encroached not only all round the forest margin to well within the boundaries of the reserve but also now occurs on natural depressions, especially the natural glades of wet grassland, within the forest.

The railway occupies a cleared $75 \mathrm{~m}$-wide strip through the long axis of the forest, which allows the extraction of valuable timber trees - principally mvule Chlorophora excelsa. This has resulted in large areas of damaged canopy and secondary growth, ranging from open grassland to areas of dense climbers and lianes scrambling over the few remaining small trees. The railway cutting now provides starting points for fires which are gradually eating away the forest. In addition, it constitutes a natural pathway for a constant stream of foot traffic from Msolwa to Mang'ula villages (map, page 495) and has opened the body of the forest to steady exploitation for poles and other products. Theoretically no exploitation of any sort is allowed within the Reserve other than by special licence from the Forestry Division, but this has not prevented extensive abuse both in the clearing of substantial areas of cultivation and in a level of pole cutting sufficient to suppress regeneration of canopy species.

The railway embankment flanked by wide, deep water-filled ditches and a broad cleared strip makes a very effective barrier - the census team had difficulty finding places to wade across - and it is inconceivable that groups of either colobus species can cross regularly between the northern and southern forest blocks. For conservation purposes we are thus dealing with two separate populations. The northern forest is smaller, more damaged and contains fewer groups of all primate species. The southern block contains an absolute 
minimum of seven groups of red colobus (more probably 12 groups, i.e. around 300 individuals) and should represent a viable population. Numbers are nevertheless dangerously low, and for this characteristically high-canopy primate any further damage to the habitat could prove critical. In other forests of the Uzungwa Highlands red colobus populations have been virtually exterminated by hunting $-C . b$. gordonorum is a favourite food of the local Wahehe people. Around Magombera the new settlers do not hunt colobus; the threat is habitat destruction.

A newly emerging threat to the survival of Magombera is the planned development of rubber plantations in the area. Despite the low rainfall for rubber production $(1500 \mathrm{~mm}$ p.a.), the high water table of the forest and surrounding flood plains could produce an economic crop if other conditions proved satisfactory.

Settlements around Magombera are of recent origin dating back to the construction of the Tazara railway. Msolwa village adjacent to Magombera is in a difficult position for future expansion. It is bounded to the north and north-west by the still expanding Kilombero Sugar Estate, by the Ruaha River to the north-east, the Selous Game Reserve to the south and east, and Magombera Forest Reserve to the south-west. Currently the weakest of conflicting interests, Magombera Forest Reserve bears the brunt of illegal encroachment and exploitation, and the Forestry Division has been unable to enforce the protection that Forest Reserve status should confer.

\section{Future Conservation Measures}

If Magombera is to be conserved and its biological values protected, it requires the stronger status of Game Reserve or National Park. To make this possible alternative areas for expanding cultivation and sources for firewood, poles and fishing sites must be made available to the villagers. A possible scheme is shown in the map. This would involve:

1. Retention of the northern forest block as a forest reserve with possibilities of utilisation by the villagers;

2. Extension of the Selous Game Reserve boundary to incorporate the southern block of Magombera Forest. The Tazara railway would form the new boundary of the Selous as far as the western edge of the forest, thereby creating a well-demarcated and easily controlled boundary;

3. Release (i.e. degazetting) of the triangle of Selous Game Reserve land north of Tazara, east of Msolwa and west of Ruaha River to give additional development space and river access to the Msolwa villagers.

The principal disadvantage of this scheme would be the loss of some partially developed rice fields; but this would be more than balanced by the gains to the villagers in terms of development space towards the Ruaha River. A further necessary management step would be the creation of a dense firebreak along the forest edge to prevent further fire incursions.

Effective conservation planning is only possible when the biological values deserving conservation have been clearly demonstrated and the natures of existing threats to those identified. In areas of high human density and increasing demand for agricultural land, a compromise between human and conservation needs has to be found. This is possible in the case of Magombera the provision of adequate forest for red colobus and the provision of sufficient development space for Msolwa villagers can be ensured by the alteration of the 


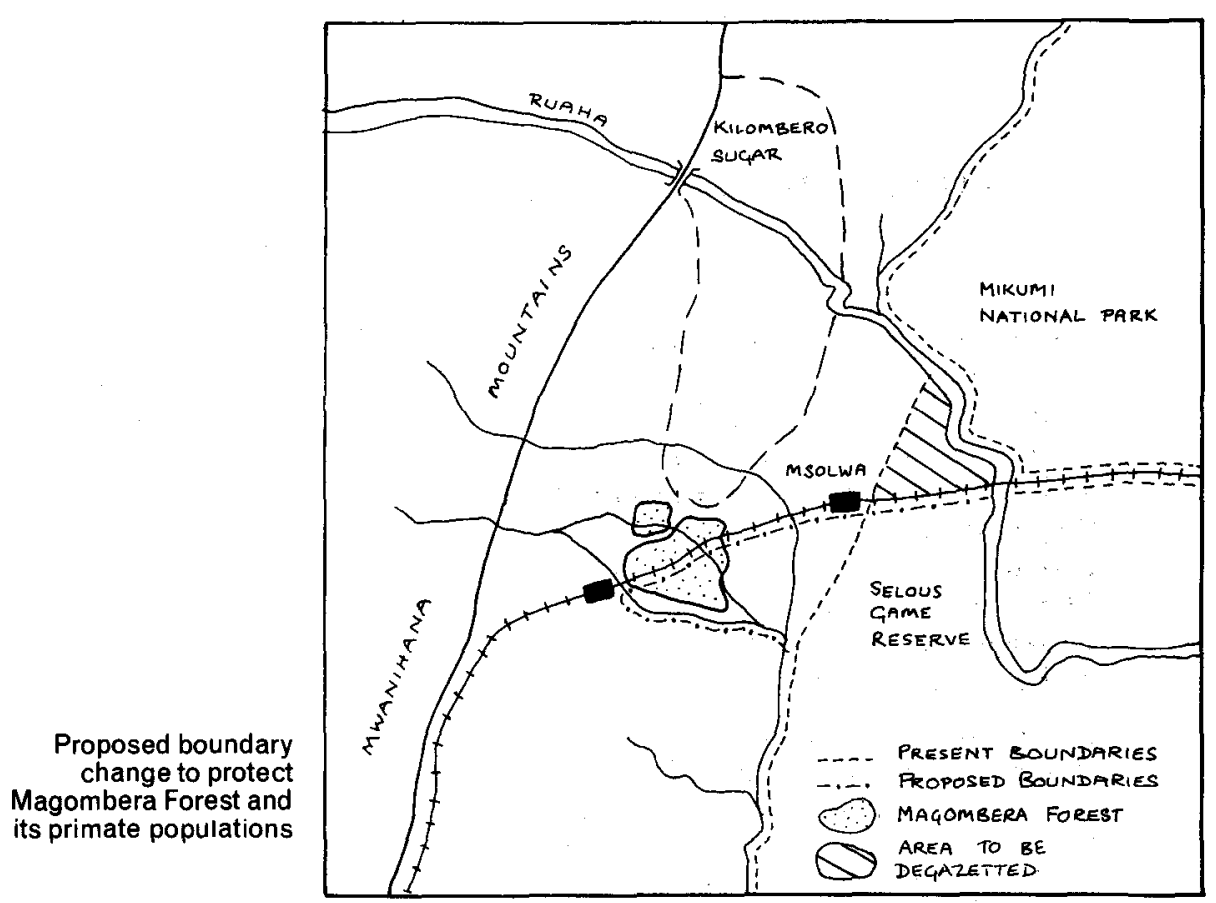

existing forest and game reserve boundaries. A detailed report showing these proposals has now been submitted to the relevant Government Departments and preliminary discussions indicated that these proposals would be effected in 1980 .

\section{Acknowledgments}

We are grateful to the Director of Forestry, and the Regional Natural Resources Officer, Morogoro for permission to work in Magombera, and to the wildlife students of the University of Dar es Salaam who assisted with the survey. Research and field course funds of the University of Dar es Salaam financed the survey.

\section{References}

1. HOMEWOOD, K.M., RODGERS, W.A. and HALL, J.B. 1979. An ecological survey of Magombera Forest Reserve, Tanzania. Mimeo Report. 75pp. Dar es Salaam.

2. IUCN Mammals Red Data Book. SCMU, Cambridge.

3. MARSH, C. 1978. Ecology and Social Organisation of the Tana River Red Colobus. $\mathrm{PhD}$ Thesis. University of Bristol.

4. STRUHSAKER, T.T. 1975. The Red Colobus. Chicago University Press.

5. STRUHSAKER, T.T. and L. Leland. 1980. Observations on two rare and endangered populations of red colobus in East Africa. Afr. F. Ecol. (in press).

University of Dar es Salaam, Tanzania

\section{Yellow-tailed Monkey Discovery}

The discovery of a new population of the yellow-tailed woolly monkey Lagothrix flavicauda in northern Peru, by Theodore A. Parker III and Linda J. Barkley, extends this recently 'rediscovered' monkey's range $200 \mathrm{~km}$ further south. A report by the discoverers will appear in the next Oryx. 